\title{
Patent Licensing in Selected European Countries
}

\author{
Rafał Wisła', Tomasz Sierotowicz ${ }^{2}$
}

\begin{abstract}
The issue of the commercialization of patents, as an exemplification of the industrial property, is mostly considered at the microeconomic level. Patent commercialization belongs to the innovation management process, which takes place in innovative organizations. Such microeconomic research approach does not take into account the phenomenon of the intellectual property simultaneous spread and use of scientific and technical knowledge in the economy. These observations lead to undertaking research on the commercial use of patents in the economy. The aim of this paper is to present the research results of the patent licensing as one of the forms of commercialization in the selected European countries in the long time period. The main purpose of undertaken research was to identify and measure the patent licensing dynamics, which is part of the one of the major research related to identify and structure recognition of patents commercialization stream. To achieve this purpose, the collection of patent metadata for the member states of the European Patent Office was used, as well as the author's own concordance IPC $\rightarrow$ NACE table. As a result of the research, some of the European countries were identified as leading, in terms of the number of licensed patents, the dynamics spread of patent property in the European economy that was set, and the branches were established, in which the emerging new industrial solutions are the subject of commercialization with the use of license contracts.
\end{abstract}

Keywords: patent, patent licensing, intellectual property commercialization.

\section{INTRODUCTION}

New knowledge and new or improved technical solutions, in order to be effectively implemented in manufacturing processes, require the fulfillment of at least two conditions (Bell \& Pavitt, 1993). The first one, of an institutional nature, is an efficient system of the commercialization of the results of research and development activities (R\&D). The second is characterized as

1 Rafał Wisła, Ph.D., Jagiellonian University, Institute of Economics, Finance and Management, ul. Prof. St. Łojasiewicza 4, 30-348 Kraków, tel.: +48 12664 5812, e-mail: rafal.wisla@uj.edu.pl.

2 Tomasz Sierotowicz, Ph.D., Jagiellonian University, Institute of Economics, Finance and Management, ul. Prof. St. Łojasiewicza 4, 30-348 Kraków, tel.: +48 12664 5812, e-mail: tomasz.sierotowicz@uj.edu.pl. 
widely understood capabilities of creation and absorption of knowledge, and technological competencies; for example, those factors that allow to begin the process of diffusion of knowledge and technology.

The intellectual property commercialization belongs to the innovation management process, which encompasses all the activities undertaken in order to bring the idea to the form that allows its use in the economy (Chesbrough, 2003; Degraff \& Quinn, 2007). The commercialization of the results of R\&D activities is a complex and multidimensional process. It covers not only implementation, but also the sale of property rights and licensing (Schaufield, 2015). It consists of a series of business and legal activities related to the commercialization of generated solutions. It is an integral element to the innovative activities of the market entities. The investigation of the mechanism of commercialization of patents, as an exemplification of industrial property, is a process that must be carried out in the following dimensions: (1) the technological area; (2) the branch of producing new/ improved technical solutions; and (3) the branch utilizing the emerging solutions.

The research on commercialization is conducted in two main and long-term directions. The first, concerns the stream of intellectual property commercialization, its structure recognition and dynamics. The second is related to measuring the influence of the intellectual property commercialization stream on the economic growth (Greenhalgh \& Rogers, 2010). Hence, the measure of the dynamics of the intellectual property licensing is one of the components of the intellectual property commercialization stream structure recognition in the long-time period.

At the macroeconomic scale, in international comparative studies, testing this process seems to be possible only with the use of patent databases. Patent information gives relatively the greatest possibilities in this regard. It runs deep in the process, in comparison to alternative methodological approaches. The main advantage of the patent information is the high flexibility of aggregation and disaggregation of researched processes.

A patent, in its economic nature, is a collection of accumulated scientific and technical knowledge. It has the ability to influence the course of management processes. In a legal sense, a patent is a set of exclusive rights to use a new solution of technical nature. It is considered to be one of the most powerful rights of intellectual property. In scientific terms, it is the culmination of R\&D activities. In economic terms, it is one of the stages of the innovation process. From the point of view of the entity that owns the patent, it is a resource and potential market value. It has a relatively high ability to transform into a production factor. It is a resource rather easily yielding to commercialization. The properties of a patent description and 
exclusive rights, cause the patent information to serve as a bridge between $R \& D$ results and its economic potential exploitation.

Patent description, statistics and databases were considered a priori as the source for large-scale datasets of primary data. Patent information can describe the following example features of the innovative activity: the novelty level of the results of conducted R\&D activities; the types of developed innovations; technological competence; innovation sources; the intensity of knowledge and technology spread (using citations of patent descriptions); and what the authors of the study suggest - the scope and dynamics of the commercial exploitation of the solutions protected by the patent monopoly, using the license information.

The literature of the subject is dominated by the microeconomic dimension of commercialization, with particular emphasis on: how to make decisions, the legal aspects of concluded license contracts, and the expected economic benefits.

Previous studies have failed to take in the problem of size and variability of the commercialization stream of patents; that is, the spread of new solutions protected by the patent monopoly in various sectors of the economy. Hence, the main aim of this article is to present the results of research on the size and dynamics of changes in the spread of patents, as an exemplification of the industrial property, in the economy, by means of license contracts, which are deemed to be one of the most frequently used forms of the commercialization of $R \& D$ results.

\section{LITERATURE REVIEW}

The methodological discussion on the scope and methods of using patent statistics in economic research (Archibugi, 1992; Basberg, 1987; Griliches, 1990; Hinze \& Schmoch, 2005; Pavitt, 1985) is not broad when compared to the methodological discussions in the areas of innovation and bibliometrics.

The method, based on the extension of the patent monopoly, is the classic and still used evaluation approach to the quality and economic usefulness of industrial knowledge, embodied in the new technical solution. It can be assumed that it is economically justified to maintain the patent monopoly in a typical business situation. The longer the monopoly is maintained, the (theoretically) harder the protected solution incorporates the economic value. Such an assumption is accepted by: Baudry and Dumont (2006); Bessen (2008); Lanjouw (1998); Lanjouw and Schankerman (1997; 2004); Pakes (1986); Schankerman (1998); and Schankerman and Pakes (1986).

Hall, Jaff \& Trajtenberg, (2005) propose an approach that uses the market valuation of the patent's portfolio, in correspondence with the 
intensity of their citation in other patent descriptions. They formulate definite conclusions, which in fact are the reflection of their many years of research using patent information: (1) the number of citations of patent claims in another patent description is a more important event than the increase in patent applications or granted rights; (2) the number of citations of patent in another patent description affects the market estimate of its holder (in practice, the shares of a listed company); and (3) the citation of a patent is a quantifiable manifestation of industrial spread of knowledge. So far, the unused attribute of patent metadata is the information about granted licenses.

Commercialization of patents is the area consisting of many interrelated legal and business processes (Webster \& Jensen, 2011). It is closely related to the commercialization of generated solutions. It is an integral and indispensable element of open innovation, based on collaboration, in terms of both R\&D activities and commercialization (Bogers, 2011; Chesbrough, 2003; Chesbrough et al., 2011; Degraff \& Quinn, 2007).

Cohen et al. $(2000,2002)$ have found that in complex industries one of the most important reasons for patenting is the use of patents in negotiations (including cross-licensing negotiations). Giuri \& Torrisi (2010) have found that cross-licensing is much more important motivation for patenting in complex product industries than in other industries.

The literature on the subject lists various forms of commercialization. Studies in this area concentrate on the presentation of commercialization paths, and ways to efficiently and effectively carry them out, in terms of R\&D results developed by both the business and science sectors (Foley, 2012; Thursby \& Kemp, 2002; Touhill \& Tuhill, 2008). One of the main forms of commercialization is licensing (Baldwin \& Clark, 1997; Campbell, Powers, Blumenthal, Biles, 2004; Dratler, 2001; Granstrand, 2011).

Studies relating to the licensing of R\&D results, concentrate on the license typology (Granstrand, 2011), legal aspects of license agreements (Bogers, 2011; Dratler, 2001; Hanel, 2006; Lichtenthaler \& Ernst, 2007; Ziegler, Ruether, Bader \& Gassman, 2013), and the business value of such contracts (Bogers, Bekkers \& Granstrand, 2012; Read, 2005).

Studies that have tried to explain the reasons for using the licensing market have focused on the supply side of the market and by highlighting the role of additional factors such as patent value, the generality of the patented technology, the scientific content of the patent and distance from the patentee's core technology, and the competitive environment (Arora et al., 2003, 2006; Gambardella et al, 2007). On PatVal-EU II, PatVal-US and PatVal-JP developing and collecting novel, systematic and more adequate science and technology indicators (Gambardella, 2011). The idea of this 
PatVal project arise from the need to answer some key questions in science, technology and innovation. The question which factors determine the rate of commercialization of inventions is one of them.

Data collections which build on the PatVal-EU survey were conducted in 2003-2005 by team members of the project (see: Giuri et al. 2007 for details). The most important findings of these studies are: on average $53.05 \%$ of patented inventions are used commercially, $5.47 \%$ of patents are sold to independent owners, $4.57 \%$ of patents have been used to found a new company, and about 8\% of patents are licensed (Gambardella, 2011). The survey makes use of a questionnaire in order to get data from the respondents. The results are static. The main aim of this article is to present results of the research on the size, dynamics of change and differences of license contracts of patents in the economies of all European Union countries in the fifteen years (1999-2013) wich used patent information database of the European Patent Office (EPO).

The conclusion of a license contract is preceded by a thorough analysis and evaluation of the business potential of the contract subject. A license contract, on the one hand, is the use of a solution protected by the patent monopoly in the real economy. On the other hand, it is the licensee's response to perceived potential demand. Hence, it is justified to claim that concluding a license agreement testifies to the real possibility of obtaining economic benefits for the licensee, as well as constituting a measure of the spread of using new solutions in the real economy.

\section{RESEARCH METHODS}

\section{Data}

The entity, while seeking a patent protection, chooses the procedure based on which the proceedings will take place. These procedures can be divided into: national, regional and international. The procedure of European patent application was selected to implement and achieve the defined research goal. Its formal basis is the European Patent Convention, to which 38 European countries have signed up (as of the end of 2014).

The collection of patent metadata for the countries covered by the research was extracted directly from the patent information database of the European Patent Office in January 2015.

In order to obtain direct access to the EPO database, the Thomson Innovation provider was used. Hence, for the research, the EPO database was used as the source of data. 
EPO database selection criteria are unified: application form, procedure for granting patents and extent of protection for applicants from all countries covered by the research. EPO database contains licensing patents data. The study uses patent information available at the end of 2013.

The years 1999-2013 are accepted as the research period. The following three considerations were crucial to choosing the research period. Firstly, the availability and completeness of patent data in the EPO mode. Secondly, the period of 15 years is long enough to capture the processes of commercialization through the licensing of patents. Thirdly, the relatively long period allows the use of basic statistical tools.

\section{Method}

Among the 38 countries belonging to the EPO, the countries for which the information about granted licenses is available were identified. These countries represent a group subject to the research in a sequence of three stages. At first, the annual value of the patent licensing efficiency ratio was set, separately for each surveyed country, according to the following equation:

$$
l c e=\frac{L_{c i}}{P_{c i}}=\frac{\sum_{i=1}^{n} l_{c i}}{\sum_{i=1}^{m} p_{c i}}
$$

where:

Ice - the annual value of the patents licensing efficiency ratio,

Lci - the annual, aggregated number of licenses granted by the country under examination,

Pci - the annual, aggregated number of patents covered by the licenses of the country under examination,

Ici - another granted license,

pci-another licensed patent,

$\mathrm{n}$ - the number of granted licenses under aggregation,

$\mathrm{m}$ - the number of licensed patents under aggregation,

$\mathrm{i}$ - another observation in time series,

$\mathrm{c}-$ another country covered by the research.

The presented indicator is a measure of the patents spread in the economy, through licensing. The indicator can assume values greater than, or equal to, 1 . If the indicator value is greater than 1 then more license contracts per licensed patent. 
The second stage of the analysis defines the dynamics of change of the efficiency ratio value, of licensing patents in the economy (Freedman, Pisani \& Purves, 2007):

$$
\begin{gathered}
\log \bar{y}_{C}=\frac{1}{n-1} \sum_{i=2}^{n} \log \frac{l c e_{i}}{l c e_{i-1}} \\
\operatorname{Ach}_{C}=\left(\bar{y}_{C}-1\right) \times 100
\end{gathered}
$$

where:

Achc - the average change rate of the efficiency ratio value of patents licensing for another country surveyed, throughout the study period,

$\bar{y} c$ - the geometric mean of chain indices of the efficiency ratio value of patents licensing for another surveyed country,

$\mathrm{n}$ - the number of observations in time series (that corresponds to the number of years of the research period),

$\mathrm{i}$ - another observation in time series,

$\mathrm{c}$ - another country covered by the research,

$\frac{l c e_{i}}{l c e_{i-1}}-$ the value of the next chain index.

The value of the average change rate indicates the dynamics of patents spread by means of licensing contracts, in the given research period.

In the third stage of the research, the author's concordance table was used, as well as the IPC $\rightarrow$ NACE binomial relationship (Okoń-Horodyńska, Wisła \& Sierotowicz, 2012); that is, to assign International Patent Classification (IPC) to The Statistical Classification of Economic Activities in the European Community (NACE). This tool allows identifying the branches from which licensed patents derive.

Patent documentation is a rich source of engineering information, information on current trends in research and invention activity, and the innovation and competitive potential of the economy and its entities. Its hierarchical structure combined with a great number of documentations (objects) form a foundation of applying specific methods intended to discover unknown dependencies, schemes and rules.

Both classification systems (NACE and IPC) have different goals and uses; hence the areas described on specific levels of these classifications are different. This applies both to specific levels of NACE and IPC, as well as to the two classifications as a whole. As a result, the task of mapping individual 
IPC codes into NACE required considering the most detailed division in both classification systems, i.e. operation on their lowest levels.

Each NACE subsection is attributed with specific classes, subclasses, groups and subgroups of the IPC. Mapping was carried out with an assumption that only one of the following: class and/or subclass and/or group and/ or subgroup can be assigned to a given subsection (industrial branch) of NACE. This approach is the result of the assumption on the creation of new or improved technical solutions by enterprises operating in the field which coincides with the branch (subsection) to which the enterprises belong according to NACE and their domestic counterparts (e.g. PKD in Poland).

\section{Limitations}

The first limitation is related to the data source. The licensing statistics are not recorded by the national statistical offices. Information about granted patent licenses is not mandatory also in the EPO database. This makes the examined phenomenon a broader range than results obtained from the research, which makes these results less accurate.

The second limitation is related to the IPC/NACE concordance table. Attribution to NACE on the fifth and the most detailed level required an insight into the complete spectrum of IPC codes (ca. 70,650 codes). For each NACE level and code on the fifth level the entire IPC spectrum was analysed horizontally, i.e. in each section, as well as vertically, from IPC classes to IPC subgroups. The purpose was to identify the classification codes which most precisely represent the area defined by a NACE code. It is judged that such an analysis warrants the most precise representation of a given NACE code by relevant IPC codes. The consequence of the work method described here is a list of IPC codes derived from various sections and the levels of this classification which most truly represent the given NACE code. The wide variation in both classifications, despite the diligence of preparing the concordance table, causes some mistakes in assigning patents to certain groups of NACE.

The statistical technique used in the research, the average rate, requires a time series composed of sufficiently large number of observations, which constituted limitations in the source data use. Hence, the main goal of the research was to identify dynamics changes of the patent licensing in the long time period.

\section{ANALYSIS}

Among the 38 countries belonging to the EPO, 16 countries were ultimately identified, for which information about granted licenses is available. The total 
number of licenses granted in the accepted research period for the selected countries, is 822 (Table 1 ).

Table 1. The number of licensed patents (1999-2013)

\begin{tabular}{|c|c|c|c|c|c|}
\hline Country & $\begin{array}{l}\text { The number } \\
\text { of licensed } \\
\text { patents }\end{array}$ & $\begin{array}{l}\text { The number } \\
\text { of granted } \\
\text { licenses }\end{array}$ & $\begin{array}{l}\text { The share } \\
\text { of licensed } \\
\text { patents } \\
(730=100 \%)\end{array}$ & $\begin{array}{l}\text { The share } \\
\text { of granted } \\
\text { licenses } \\
(822=100 \%)\end{array}$ & $\begin{array}{l}\text { The ratio of } \\
\text { the number } \\
\text { of granted } \\
\text { licenses to } \\
\text { the number } \\
\text { of licensed } \\
\text { patents }\end{array}$ \\
\hline Switzerland & 10 & 10 & $1.37 \%$ & $1.22 \%$ & 1.00 \\
\hline Sweden & 45 & 54 & $6.16 \%$ & $6.57 \%$ & 1.20 \\
\hline Spain & 6 & 8 & $0.82 \%$ & $0.97 \%$ & 1.33 \\
\hline Norway & 3 & 3 & $0.41 \%$ & $0.36 \%$ & 1.00 \\
\hline Netherlands & 18 & 18 & $2.47 \%$ & $2.19 \%$ & 1.00 \\
\hline Italy & 18 & 21 & $2.47 \%$ & $2.55 \%$ & 1.17 \\
\hline Ireland & 4 & 4 & $0.55 \%$ & $0.49 \%$ & 1.00 \\
\hline Iceland & 1 & 1 & $0.14 \%$ & $0.12 \%$ & 1.00 \\
\hline United Kingdom & 199 & 226 & $27.26 \%$ & $27.49 \%$ & 1.14 \\
\hline Germany & 30 & 34 & $4.11 \%$ & $4.14 \%$ & 1.13 \\
\hline France & 371 & 408 & $50.82 \%$ & $49.64 \%$ & 1.10 \\
\hline Finland & 1 & 1 & $0.14 \%$ & $0.12 \%$ & 1.00 \\
\hline Denmark & 11 & 21 & $1.51 \%$ & $2.55 \%$ & 1.91 \\
\hline Czech Republic & 1 & 1 & $0.14 \%$ & $0.12 \%$ & 1.00 \\
\hline Belgium & 7 & 7 & $0.96 \%$ & $0.85 \%$ & 1.00 \\
\hline Austria & 5 & 5 & $0.68 \%$ & $0.61 \%$ & 1.00 \\
\hline Total & 730 & 822 & $100 \%$ & $100 \%$ & \\
\hline
\end{tabular}

In the analyzed set of metadata information about patents (Table 1), which were granted in the European application mode, and for which licenses were granted at the same time using the criterion of the number of licenses issued per one patent, the leader of the research group is Denmark (1.9 license for one technical solution protected by patent monopoly). Next are: Spain (with the index value of 1.3); Sweden (1.2); Italy (near 1.2); the United Kingdom, Germany and France (1.10-1.15). 
Taking into account the share of licensed patents of a given country of the total number of licensed patents of all 16 states, France becomes the leader (with a share of nearly $51 \%$ of the licensed patents in the researched group). The United Kingdom is second (with a share of $27.3 \%$ ), the third is Sweden (6.2\% share), and Germany is fourth ( $4.1 \%$ share). The total share of these four countries of the number of licensed patents of the 16 countries, is $88.4 \%$. In the later part of the analysis, these countries are deemed to be the leading ones, and therefore they alone are the subjects of further analysis.

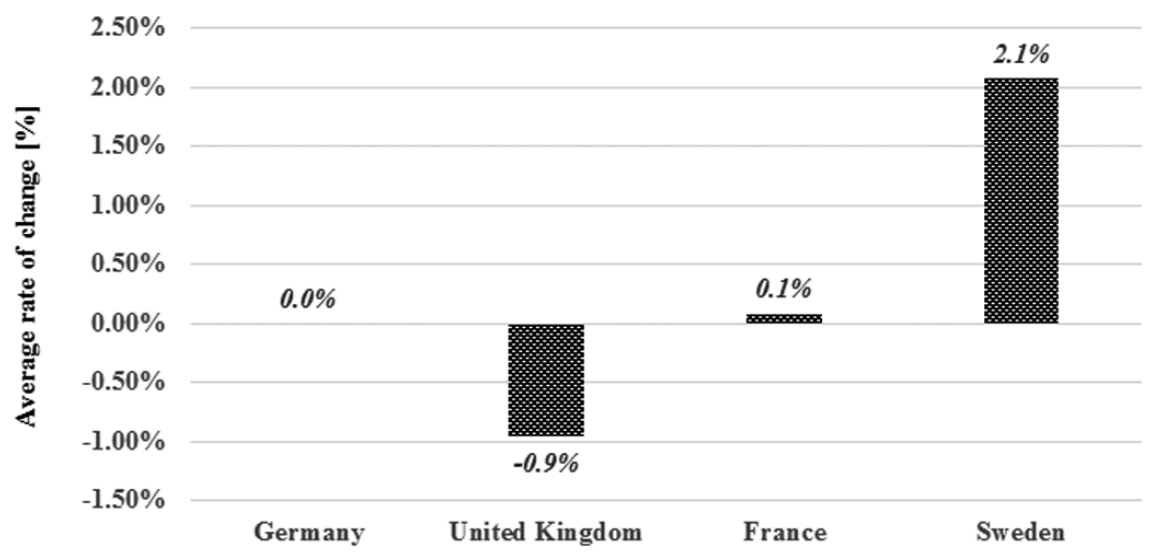

Figure 1. Average change rate of the efficiency ratio value of patents licensing

The highest positive value of the average change rate of the efficiency ratio value of patents spread in the European economy, through the licensing of patents, was calculated for Sweden (2.1\%). It means that the number of granted licenses to the number of licensed patents in Sweden increased year to year, average on the $2.1 \%$ in the entire research period. A tendency similar in direction, though having a poor growth dynamic, can be seen in France $(0.1 \%)$. It means that the number of granted licenses to the number of licensed patents in French increased year to year, average on the $0.1 \%$ in the entire research period. Comparing these two countries, the number of licenses granted to the number of licensed patents increased in year to year, average of 21 times faster in Sweden than in France. The opposite tendency was identified in United Kingdom, where the number of granted licenses to the number of licensed patents decreased year to year, average on the $0.9 \%$ in the entire research period. It means that the licensing spread in United Kingdom economy shrank throughout the entire study period. In the case of Germany, there is a constant spread number of granted licenses to the 
licenses patents. In other European countries taken under research, there was insufficient data series in order to identify above-mentioned direction of licensing patents spread.

Using the binomial relationship IPC $\rightarrow$ NACE, it was possible to identify branches in the group of four leading countries, which produce new product and process solutions that are the subjects of the most intense licensing. The results are presented in Table 2.

Table 2. The share of licensed patents in the branches of economies

\begin{tabular}{|c|c|c|c|c|c|}
\hline $\begin{array}{l}\text { Statistical Classification of Economic } \\
\text { Activities in the European Community }\end{array}$ & $\begin{array}{l}\text { Germany } \\
(\%)\end{array}$ & $\begin{array}{l}\text { United } \\
\text { Kingdom } \\
\text { (\%) }\end{array}$ & $\begin{array}{l}\text { France } \\
(\%)\end{array}$ & $\begin{array}{l}\text { Sweden } \\
\text { (\%) }\end{array}$ & Total (\%) \\
\hline $\begin{array}{l}\text { Agriculture, hunting and related service } \\
\text { activities }\end{array}$ & $0.00 \%$ & $0.50 \%$ & $1.08 \%$ & $0.00 \%$ & $0.78 \%$ \\
\hline $\begin{array}{l}\text { Forestry, logging and related service } \\
\text { activities }\end{array}$ & $0.00 \%$ & $0.00 \%$ & $0.00 \%$ & $0.00 \%$ & $0.00 \%$ \\
\hline $\begin{array}{l}\text { Fishing, fish farming and related service } \\
\text { activities }\end{array}$ & $0.00 \%$ & $1.01 \%$ & $0.27 \%$ & $0.00 \%$ & $0.47 \%$ \\
\hline $\begin{array}{l}\text { Mining of coal and lignite; extraction of } \\
\text { peat }\end{array}$ & $0.00 \%$ & $0.00 \%$ & $0.00 \%$ & $0.00 \%$ & $0.00 \%$ \\
\hline $\begin{array}{l}\text { Extraction of crude petroleum and } \\
\text { natural gas; service activities incidental to } \\
\text { oil and gas extraction, excluding surveying }\end{array}$ & $0.00 \%$ & $1.51 \%$ & $0.00 \%$ & $0.00 \%$ & $0.47 \%$ \\
\hline Mining of metal ores & $0.00 \%$ & $0.00 \%$ & $0.00 \%$ & $0.00 \%$ & $0.00 \%$ \\
\hline Other mining and quarrying & $0.00 \%$ & $0.00 \%$ & $0.00 \%$ & $0.00 \%$ & $0.00 \%$ \\
\hline $\begin{array}{l}\text { Manufacture of food products and } \\
\text { beverages }\end{array}$ & $6.67 \%$ & $10.55 \%$ & $5.12 \%$ & $2.22 \%$ & $6.67 \%$ \\
\hline Manufacture of tobacco products & $0.00 \%$ & $0.00 \%$ & $0.00 \%$ & $0.00 \%$ & $0.00 \%$ \\
\hline Manufacture of textiles & $0.00 \%$ & $1.01 \%$ & $0.81 \%$ & $0.00 \%$ & $0.78 \%$ \\
\hline $\begin{array}{l}\text { Manufacture of wearing apparel; dressing } \\
\text { and dyeing of fur }\end{array}$ & $0.00 \%$ & $0.00 \%$ & $0.81 \%$ & $0.00 \%$ & $0.47 \%$ \\
\hline $\begin{array}{l}\text { Tanning and dressing of leather; } \\
\text { manufacture of luggage, handbags, } \\
\text { saddlery, harness and footwear } \\
\text { Manufacture of wood and of products }\end{array}$ & $0.00 \%$ & $0.50 \%$ & $0.81 \%$ & $2.22 \%$ & $0.78 \%$ \\
\hline $\begin{array}{l}\text { of wood and cork, except furniture; } \\
\text { manufacture of articles of straw and } \\
\text { plaiting materials }\end{array}$ & $0.00 \%$ & $0.00 \%$ & $0.81 \%$ & $0.00 \%$ & $0.47 \%$ \\
\hline $\begin{array}{l}\text { Manufacture of pulp, paper and paper } \\
\text { products }\end{array}$ & $13.33 \%$ & $0.00 \%$ & $1.08 \%$ & $0.00 \%$ & $1.24 \%$ \\
\hline $\begin{array}{l}\text { Publishing, printing and reproduction of } \\
\text { recorded media }\end{array}$ & $6.67 \%$ & $1.01 \%$ & $1.89 \%$ & $20.00 \%$ & $3.10 \%$ \\
\hline $\begin{array}{l}\text { Manufacture of coke, refined petroleum } \\
\text { products and nuclear fuel }\end{array}$ & $0.00 \%$ & $0.00 \%$ & $0.00 \%$ & $0.00 \%$ & $0.00 \%$ \\
\hline $\begin{array}{l}\text { Manufacture of chemicals and chemical } \\
\text { products }\end{array}$ & $23.33 \%$ & $21.61 \%$ & $15.90 \%$ & $4.44 \%$ & $17.21 \%$ \\
\hline $\begin{array}{l}\text { Manufacture of rubber and plastic } \\
\text { products }\end{array}$ & $0.00 \%$ & $0.50 \%$ & $1.62 \%$ & $0.00 \%$ & $1.09 \%$ \\
\hline
\end{tabular}




\begin{tabular}{|c|c|c|c|c|c|}
\hline $\begin{array}{l}\text { Statistical Classification of Economic } \\
\text { Activities in the European Community }\end{array}$ & $\begin{array}{l}\text { Germany } \\
(\%)\end{array}$ & $\begin{array}{l}\text { United } \\
\text { Kingdom } \\
\text { (\%) }\end{array}$ & $\begin{array}{l}\text { France } \\
\text { (\%) }\end{array}$ & $\begin{array}{l}\text { Sweden } \\
\text { (\%) }\end{array}$ & Total (\%) \\
\hline $\begin{array}{l}\text { Manufacture of other non-metallic } \\
\text { mineral products }\end{array}$ & $3.33 \%$ & $1.01 \%$ & $5.66 \%$ & $0.00 \%$ & $3.72 \%$ \\
\hline Manufacture of basic metals & $0.00 \%$ & $1.01 \%$ & $0.54 \%$ & $0.00 \%$ & $0.62 \%$ \\
\hline $\begin{array}{l}\text { Manufacture of fabricated metal } \\
\text { products, except machinery and } \\
\text { equipment }\end{array}$ & $0.00 \%$ & $6.53 \%$ & $3.50 \%$ & $0.00 \%$ & $4.03 \%$ \\
\hline $\begin{array}{l}\text { Manufacture of machinery and } \\
\text { equipment not elsewhere classified }\end{array}$ & $13.33 \%$ & $6.53 \%$ & $10.24 \%$ & $0.00 \%$ & $8.53 \%$ \\
\hline $\begin{array}{l}\text { Manufacture of office machinery and } \\
\text { computers }\end{array}$ & $0.00 \%$ & $3.52 \%$ & $0.27 \%$ & $57.78 \%$ & $5.27 \%$ \\
\hline $\begin{array}{l}\text { Manufacture of electrical machinery and } \\
\text { apparatus not elsewhere classified }\end{array}$ & $20.00 \%$ & $3.02 \%$ & $3.50 \%$ & $0.00 \%$ & $3.88 \%$ \\
\hline $\begin{array}{l}\text { Manufacture of radio, television and } \\
\text { communication equipment and apparatus }\end{array}$ & $3.33 \%$ & $6.03 \%$ & $2.70 \%$ & $0.00 \%$ & $3.57 \%$ \\
\hline $\begin{array}{l}\text { Manufacture of medical, precision and } \\
\text { optical instruments, watches and clocks }\end{array}$ & $3.33 \%$ & $25.63 \%$ & $11.86 \%$ & $4.44 \%$ & $15.19 \%$ \\
\hline $\begin{array}{l}\text { Manufacture of motor vehicles, trailers } \\
\text { and semi-trailers }\end{array}$ & $0.00 \%$ & $1.01 \%$ & $12.13 \%$ & $0.00 \%$ & $7.29 \%$ \\
\hline $\begin{array}{l}\text { Manufacture of other transport } \\
\text { equipment }\end{array}$ & $6.67 \%$ & $2.01 \%$ & $5.39 \%$ & $0.00 \%$ & $4.03 \%$ \\
\hline $\begin{array}{l}\text { Manufacture of furniture; manufacturing } \\
\text { not elsewhere classified }\end{array}$ & $0.00 \%$ & $2.51 \%$ & $1.35 \%$ & $0.00 \%$ & $1.55 \%$ \\
\hline Recycling & $0.00 \%$ & $0.00 \%$ & $0.81 \%$ & $0.00 \%$ & $0.47 \%$ \\
\hline Construction & $0.00 \%$ & $3.02 \%$ & $11.86 \%$ & $8.89 \%$ & $8.37 \%$ \\
\hline Total & $100 \%$ & $100 \%$ & $100 \%$ & $100 \%$ & $100 \%$ \\
\hline
\end{tabular}

The largest number of new solutions is created in the research group of four countries, in the manufacture of chemicals and the chemical products branch. The solutions are the subject of further commercialization through licensing (17.2\% of all licensed patents). The individual branches display the following characteristics: the manufacture of medical, precision and optical instruments, watches and clocks (15.2\%); the manufacture of machinery and equipment (8.5\%); construction (8.4\%); the manufacture of motor vehicles, trailers and semi-trailers (7.3\%); the manufacture of food products and beverages (6.7\%); and the manufacture of office machinery and computers (5.3\%). The share of licensed patents in other branches is below $5 \%$.

The following figures show the results of using the IPC $\rightarrow$ NACE table, separately for each country included in the research (Figure 2). 


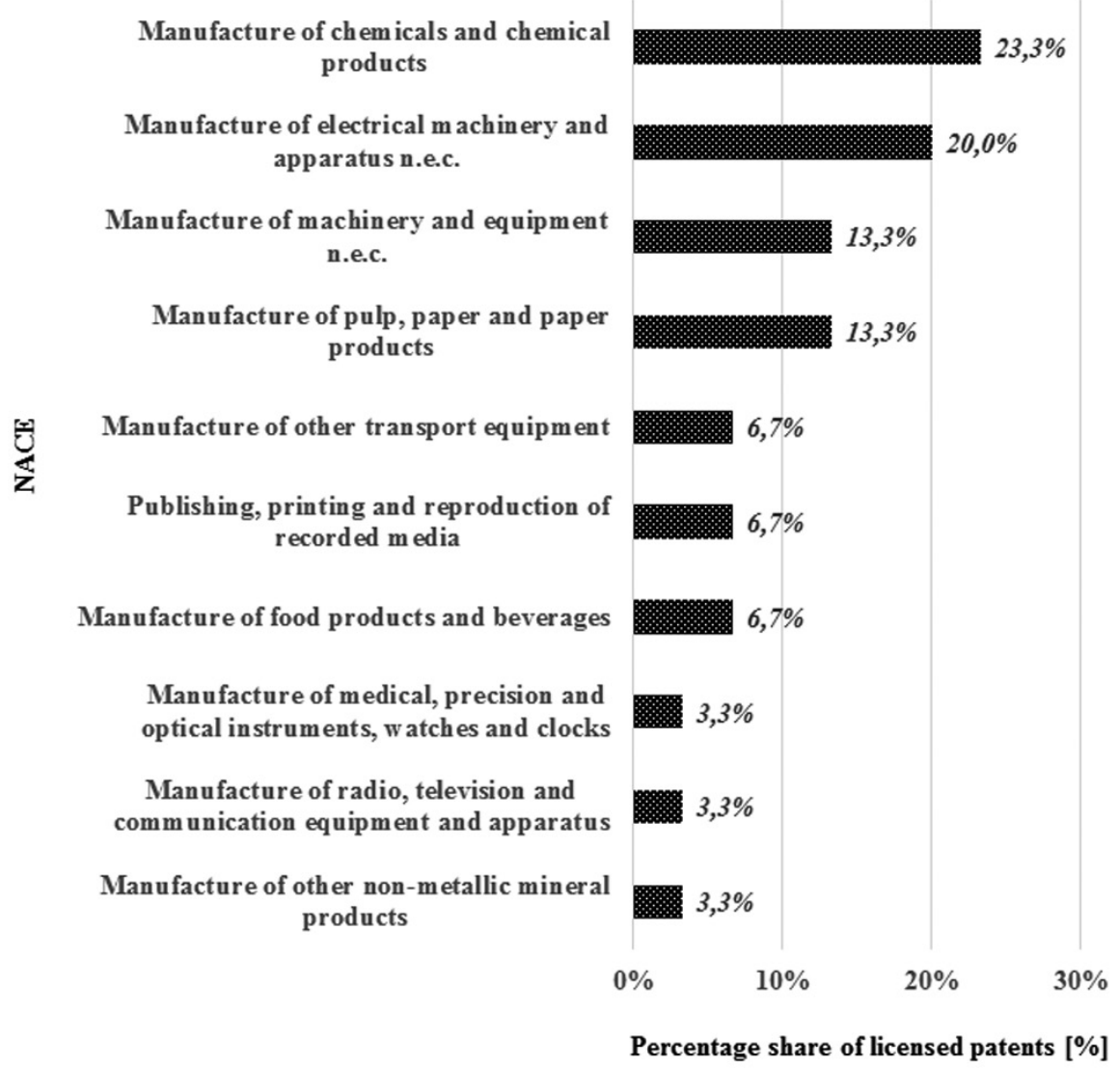

Figure 2. The structure of licensed patents according to the branches of the German economy

In the case of the German economy, four branches emerge where the new solutions are the subject of licensing. These are: the manufacture of chemicals and chemical products $(23.3 \%$ of all the licensed patents in the researched group); the manufacture of electrical machinery and apparatus (20\%); the manufacture of machinery and equipment, and of pulp, paper and paper products (13.3\%). 


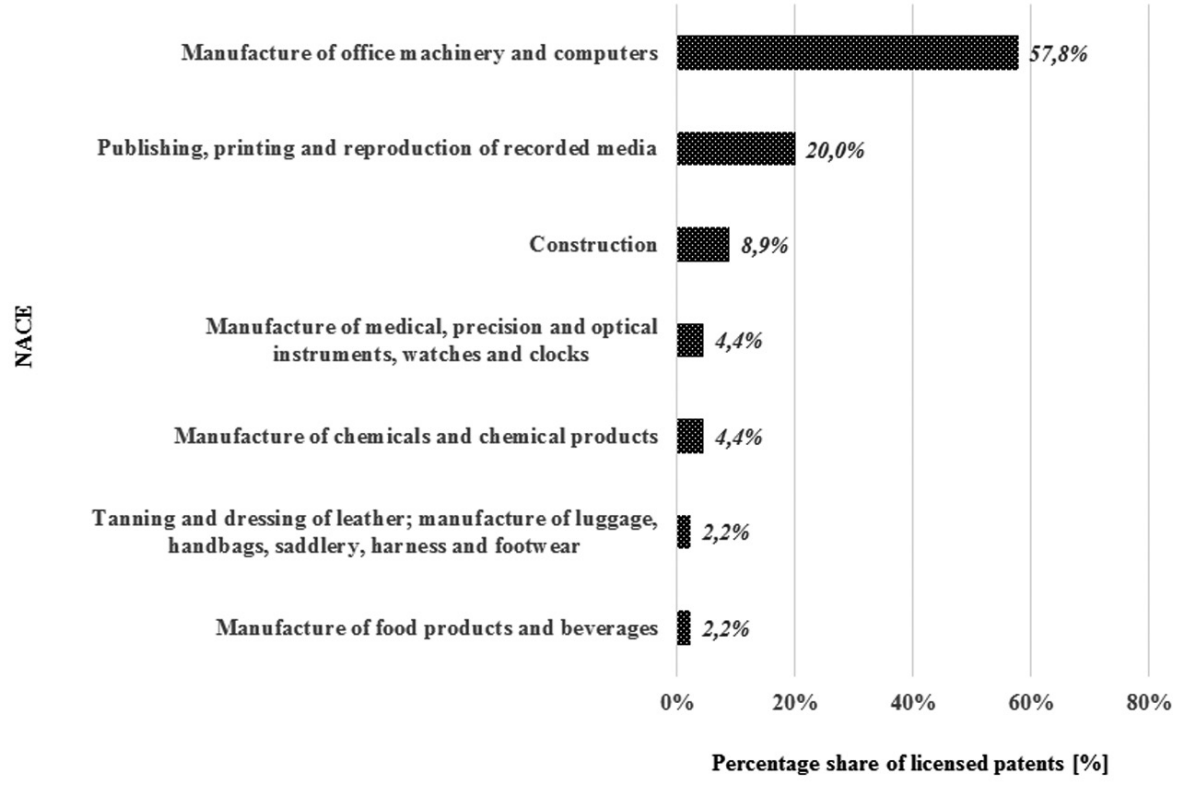

Figure 3. The structure of licensed patents according to the branches of the Swedish economy

In the case of the Swedish economy (Figure 3) the manufacture of office machinery and computers $(57.8 \%)$ is the leader. Attention should also be paid to publishing, printing and the reproduction of recorded media (20\%).

In the case of the United Kingdom (Figure 4), the largest number of licensed patents include the following branches: the manufacture of medical, precision and optical instruments, watches and clocks (25.6\%); the manufacture of chemicals and chemical products $(21.6 \%)$; and the manufacture of food products and beverages (10.6\%). The share of the other branches is below 10\%. Results for France are shown in Figure 5.

In the case of the French economy (Figure 5), the distribution of the share of licensed patents on the individual branches, substantially coincides with the distribution for the whole group of the researched countries. These are: the manufacture of chemicals and chemical products (15.9\%); the manufacture of motor vehicles, trailers and semi-trailers (12.1\%); the manufacture of medical, precision and optical instruments, watches and clocks, and construction (11.9\%); and the manufacture of machinery and equipment (10.2\%). The share of the other branches is below $10 \%$. 


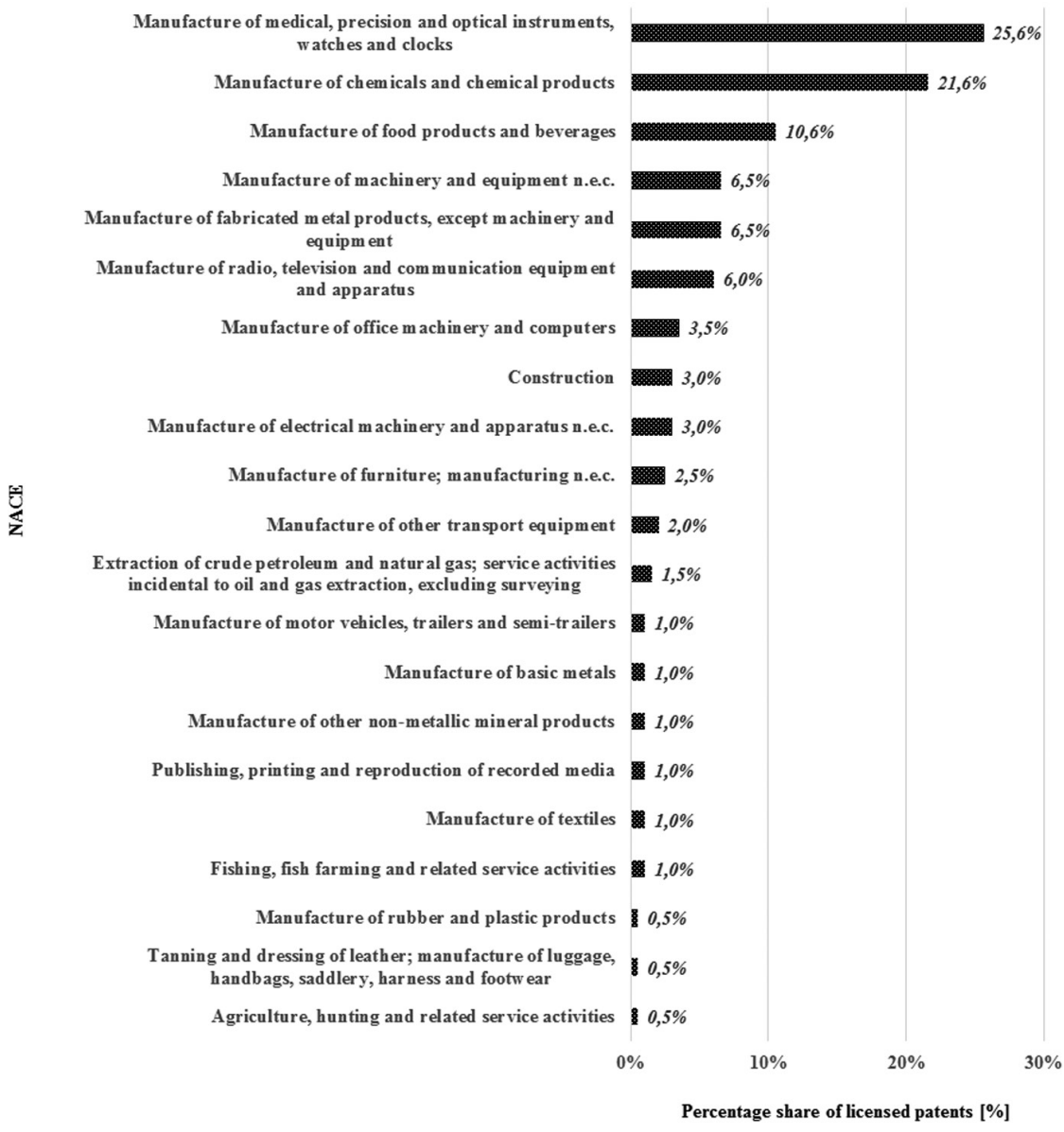

Figure 4. The structure of licensed patents according to the branches of the U.K. economy 


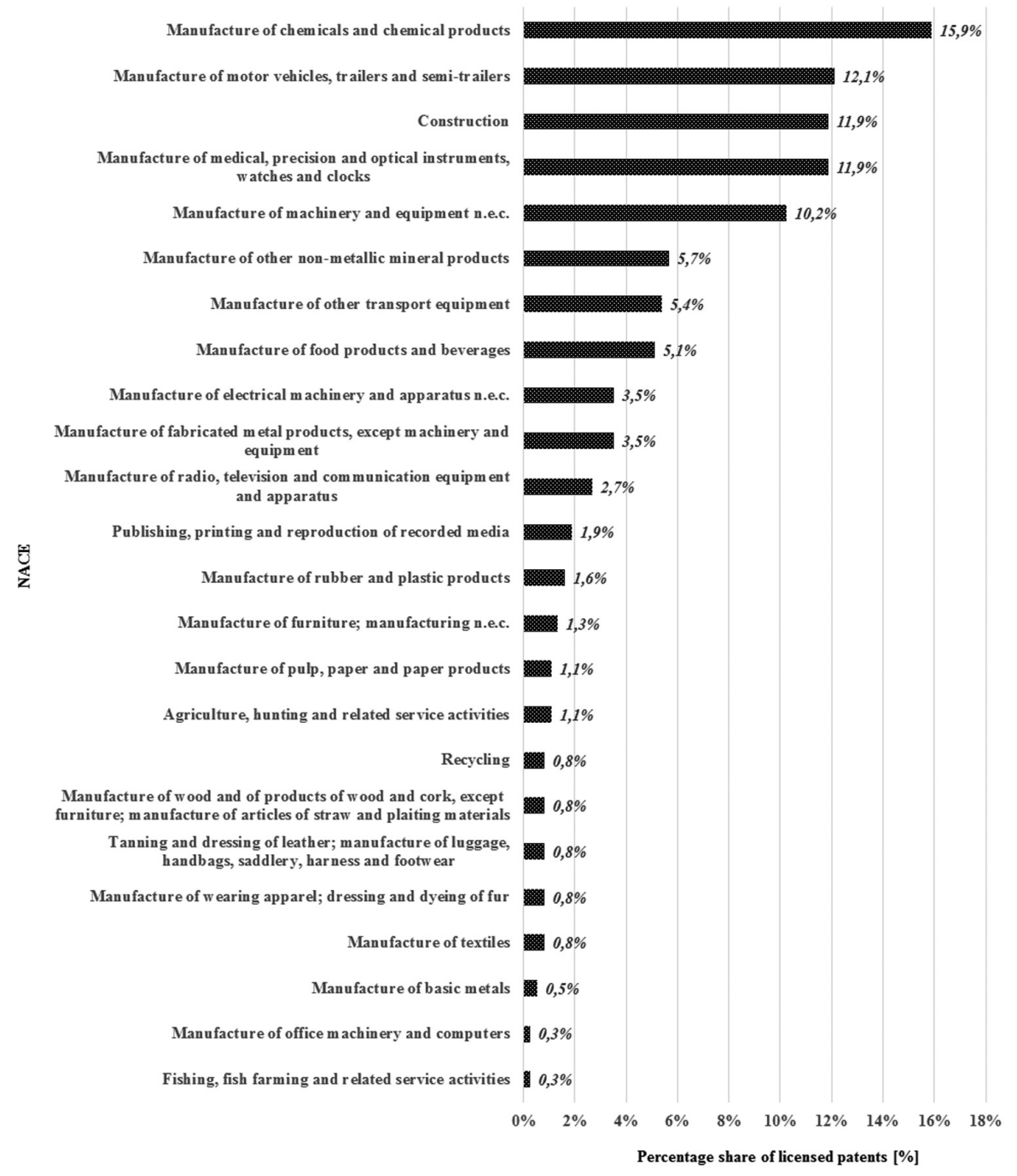

Figure 5. The structure of licensed patents according to the branches of the French economy

\section{CONCLUSION}

The research problem of this article was to identify changes and spread of patent licensing in European countries, in the fifteen years (1999-2013). The research results, based on performed literature research and calculations, allow to formulate the following conclusions:

1) In the literature on the commercialization of patents, as an exemplification of the industrial property, the microeconomic dimension of this process 
is dominant. Especially highlighted are: the method of making a decision, legal and business aspects of the concluded license contracts, and the assessment methods of the expected economic benefits.

2) The examined licensing contracts identified in the EPO database, covering a period of fifteen years, were concluded for new solutions, representing the following branches: the manufacture of chemicals and chemical products; and the manufacture of medical, precision and optical instruments, watches and clocks.

3) Taking into account the share of licensed patents of a given country of the total number of licensed patents of all 16 states, France is the leader (with a share of nearly $51 \%$ of the licensed patents in the researched group). The United Kingdom is second (with a share of $27.3 \%$ ), the third is Sweden (6.2\% share), and Germany is fourth ( $4.1 \%$ share). The total share of these four countries of the number of licensed patents of the 16 countries, is $88.4 \%$.

4) The average change rate of the efficiency ratio value, defined as the annual number of licenses granted in the country under examination to the annual number of licensed patents in this country, indicates the increase or decrease of licensing patents spread through the economy of this country. Based on the performed calculations, the highest value of the average change rate of the efficiency ratio was identified in Sweden: $2.1 \%$. It means that the number of granted licenses to the number of licensed patents in Sweden increased year to year, on average by $2.1 \%$ in the entire research period.

The similar tendency in direction was identified in France (ratio of $0.1 \%$ ). It means that the number of granted licenses to the number of licensed patents in French increased year to year, on average by the $0.1 \%$ in the entire research period. Comparing these two countries, the number of licenses granted to the number of licensed patents increased year to year, on average 21 times faster in Sweden than in France. The opposite tendency was identified in United Kingdom, where the number of granted licenses to the number of licensed patents decreased year to year, average on the $0.9 \%$ in the entire research period. It means that the licensing spread in United Kingdom economy shrank throughout the entire study period. In the case of Germany, there is a constant spread number of granted licenses to the licenses patents. In other European countries taken under research, there was insufficient data series in order to identify above-mentioned direction of licensing patents spread.

5) The major challenges to the public databases of patent information and their commercial suppliers include collecting information about the codes of economic classification of entities applying for patent protection (which will lead to an increase in the efficiency of sectoral research), and annotations on granted licenses and changes of the patentee (which enables research on the secondary market of industrial property trade). 
Decisions on patent licensing are influenced by many factors, both macroeconomic and microeconomic. It is important to notice that such decision is taken by the inventor or patent owner.

\section{References}

Archibugi, D., Pianta, M. (1996). Measuring Technological Change through Patents and Innovation Surveys. Technovation, 16(9), 451-468.

Arrow, K. J. (1962). Economic Welfare and the Allocation of Resources for Invention. In: R. Nelson (Ed.), The Rate and Direction of Inventive Activity: Economic and Social Factors (pp. 609-626). Princeton, NY: National Bureau of Economic Research, Princeton University Press.

Baldwin, C., Clark K. (1997). Sun Wars: Competition within a Modular Cluster. In: D. B. Yoffie (Ed.), Competing in the Age of Digital Convergence (pp. 123-157). Boston, MA: Harvard Business School Press.

Basberg, B. (1987). Patents and the Measurement of Technological Change: A Survey of the Literature. Research Policy, 16, 131-141.

Baudry, M., Dumont, B. (2006). Patent Renewals as Options: Improving the Mechanism for Weeding Out Lousy Patents. Review of Industrial Organization, 28(1), 41-62.

Bell, M., Pavitt, K. (1993). Technological Accumulation and Industrial Growth: Contrasts Between Developed and Developing Countries. Industrial and Corporate Change, 2, 157-210.

Bogers, M. (2011). The Open Innovation Paradox: Knowledge Sharing and Protection in R\&D Collaborations. European Journal of Innovation Management, 14(1), 93-117.

Bogers, M., Bekkers, R., Granstrand, O. (2012). Intellectual Property and Licensing Strategies in Open Collaborative Innovation. In: C. de Pablos Heredero, D. López (Eds.), Open Innovation at Firms and Public Administration: Technologies for Value Creation (pp. 37-58). Hershey, PA: IGI Global.

Burke, P., Reitzig, M. (2007). Measuring Patent Assessment Quality-Analyzing the Degree and Kind of (In)consistency in Patent Offices' Decision Making. Research Policy, 36, 1404-1430.

Campbell, G.E., Powers, B.J., Blumenthal, D., Biles, D. (2004). Inside the Triple Helix: Technology Transfer and Commercialization in The Life Sciences. Health Affairs, 23(1), 64-76.

Chawala, H.S. (2007). Managing Intellectual Property Rights for Better Transfer and Commercialization of Agricultural Technologies. Journal of Intellectual Property Rights, 12, 330-340.

Chesbrough, H. (2003). Open Innovation: the new imperative for creating and profiting from technology. Boston, MA: Harvard Business School Press.

Davis, L. (2004). Intellectual Property Rights, Strategy and Policy. Economics of Innovation and New Technology, 13(5), 399-415.

Degraff, J., Quinn, E. (2007). Leading Innovation. New York: McGraw-Hill. 
Dratler, J. (1994). Licensing of Intellectual Property. New York: Law Publishing Company.

Dyer, J., Gregersen, H., Christensen, C. (2011). The Innovator's DNA. Boston, MA: Harvard Business Review Press.

Florida, R. (2010). The Flight of the Creative Class: The New Global Competition for Talent. New York: HarperCollins.

Foley, H. (2012). A New Approach to Intellectual Property, Management and Industrially Funded Research at Penn State. Research-Technology Management, September/October, 1-6.

Freedman, D., Pisani, R., Purves, R. (2007). Statistics. New York: W. W. Norton and Company.

Freeman, C. (1982). The Economics of Industrial Innovation. Cambridge, MA: MIT Press.

Granstrand, O. (2011). Industrial Innovation Economics and Intellectual Property. Gothenburg: Svenska Kulturkompaniet.

Greenhalgh, Ch., Rogers M. 2010. Innovation, Intellectual Property, and Economic Growth. Princeton, NY: Princeton University Press.

Griliches, Z. (1990). Patent Statistics as Economic Indicators: A Survey. Journal of Economic Literature, 28, 1661-1707.

Grossman, G. M., Helpman, E. (1991). Innovation and Growth in the Global Economy. Cambridge: MIT Press.

Hall, B. H., Jaffe, A., Trajtenberg, M. (2005). Market Value and Patent Citations. The RAND Journal of Economics, 36, 16-38.

Hanel, P. (2006). Intellectual Property Rights Business Management Practices: A Survey of the Literature. Technovation, 26, 895-931.

Hinze, S., Schmoch, U. (2005). Opening the Black Box. Analytical approaches and their impact on the outcome of statistical patent analyses. In W. Glänzel, H. Moed, U. Schmoch (Eds.), Handbook of Quantitative Science and Technology Research: The Use of Publication and Patent Statistics in Studies on R\&D Systems (pp. 215-235). Dordrecht/Boston/London: Kluwer Academic Publishers.

Lanjouw, J. O. (1998). Patent Protection in the Shadow of Infringement: Simulation Estimations of Patent Value. The Review of Economic Studies, 65, 671-710.

Lanjouw, J. O., Schankerman, M. (1997). Stylised Facts of Patent Litigation: Value, Scope and Ownership. NBER working paper series. Cambridge, MA: National Bureau of Economic Research.

Lanjouw, J. O., Schankerman, M. (2004). Patent Quality and Research Productivity: Measuring Innovation with Multiple Indicators. The Economic Journal, 114, 441-465.

Lichtenthaler, U. (2005). External commercialization of knowledge: Review and research agenda. International Journal of Management Reviews, 7(4), 231-255. 
Lichtenthaler, U., Ernst, H. (2007). External Technology Commercialization in Large Firms: Results of a Quantitative Benchmarking Study. $R \& D$ Management, 37, 383-397.

Okoń-Horodyńska, E., Wisła, R., Sierotowicz, T. (2012). Measuring Patent Activity of Economic Branches with the Use of Concordance Tables. Warsaw: Patent Office of The Republic of Poland.

Pakes, A. (1986). Patents as Options: Some Estimates of the Value of Holding European Patent Stocks. Econometrics, 54, 755-784.

Pavitt, K., (1985). Patent Statistics as Indicators of Innovation Activities. Scientometrics, 7, 77-99.

Rappert, B., Webster, A. (1997). Regimes of Ordering: The Commercialization of Intellectual Property in Industrial-Academic Collaborations. Technology Analysis and Strategic Management, 9(2), 115-130.

Read, C. (2005). Survey of Intellectual Property Commercialization in the Higher Education Sector, 2003. Ottawa, Canada: Published by authority of the Minister responsible for Statistics.

Schankerman, M. (1998). How Valuable is Patent Protection? Estimates by Technology Field. The RAND Journal of Economics, 29, 77-107.

Schankerman, M., Pakes, A. (1986). Estimates of The Value of Patent Rights in European Countries During The Post-1950 Period. Economic Journal, 96, 1052-1076.

Schmookler, J. (1952). The Changing Efficiency of the American Economy: 1869-1938. The Review of Economic Statistics, 34, 214-321.

Schaufield J. (2015). Commercializing Innovation: Turning Technology Breakthroughs into Products. New York: Apress.

Schumpeter, J. (1934). The Theory of Economic Development. Cambridge, MA: Harvard University Press.

Shapiro, C. (2001). Navigating the Patent Thicket: Cross Licenses, Patent Pools, and Standard Setting. In: A.B. Jaffe, J. Lerner, S. Stern (Eds.), Innovation Policy and the Economy 1 (pp. 119-150). Cambridge, MA: MIT Press.

Thursby, J., Kemp, S. (2002). Growth and Productive Efficiency of University Intellectual Property Licensing. Research Policy, 31, 109-124.

Touhill, C. J., Tuhill, J. G. (2008). Commercialization of Innovative Technologies: Bringing Good Ideas to the Marketplace. New York: Wiley and Sons.

Webster, E., Jensen, H. P. (2011). Do Patents Matter for Commercialization? Journal of Law and Economics, 54(2), 431-453.

Ziegler, N., Ruether, R., Bader, A. M., Gassman, O. (2013). Creating Value through External Intellectual Property Commercialization: A Disruptive Capacity View. Journal of Technological Transfer, 38, 930-949.

\section{Biographical notes}

Rafał Wisła, Ph.D., is employed at the Department of Economics and Innovation, the Institute of Economics, Finance and Management of the Jagiellonian University in Krakow (Poland). His main interest and research 
areas include a variety of economic subjects, which includes technological changes and innovation activity. Selected publications: "The Regional Patterns of Technical Knowledge Accumulation in Central and Eastern Europe Countries" (2014), Polish Scientific Publishers PWN, Warsaw; "Problems with the Creation of an Integrated IT and Institutional Infrastructure for Science and Education in Poland" (2013), Polish Economic Society, Warsaw; "Measuring Patent Activity of Economic Branches Using Concordance Tables" (2012), Polish Economic Society, Warsaw.

Tomasz Sierotowicz, Ph.D., Eng., is employed at the Department of Economics and Innovation, the Institute of Economics, Finance and Management of the Jagiellonian University in Krakow (Poland). Participation in research projects, including: "The Trends of the Selected Technologies of the Information Society until 2025", "The Establishment of the Universal, Open, Hosting and Communication Repository Platform for the Network Resources of Knowledge to Be Used by Science, Education and Open Knowledge Society". Selected international experience: ICS-Scranton, PA, (USA); Cleveland Institute of Electronics, Cleveland, OH, (USA); ESL, Princeton, NJ, (USA). His interest areas include the development of strategies and innovation, strategic management, the theory and practice of innovation development from the macro and micro perspective, the economics of the ICT change.

\section{Abstrakt (in Polish)}

Zagadnienie komercjalizacji własności przemysłowej jest rozpatrywane najczęściej w ujęciu mikroekonomicznym. Komercjalizacja stanowi ważny element procesu zarzqdzania innowacjami. Dotychczasowe badania w tym obszarze nie uwzględniaja zjawiska jednoczesnego rozprzestrzeniania i wykorzystania wiedzy naukowo-technicznej w gospodarce. Spostrzeżenia te skłaniaja do podjęcia badań nad komercyjnym wykorzystaniem własności przemysłowej w gospodarce. Celem opracowania jest prezentacja wyników badań licencjonowania własności przemysłowej, jako jednej z form komercjalizacji, w wybranych krajach europejskich. Identyfikacja dynamiki zmian w zakresie skali licencjonowania własności intelektualnej wpisuje się w jeden z głównych kierunków badań dotyczqcych identyfikacji i rozpoznania struktury strumienia komercjalizacji. Dla realizacji tego celu wykorzystano zbiór metadanych patentowych dla krajów członkowskich Europejskiego Urzędu Patentowego oraz autorskq tablice tacznikowq IPC $\rightarrow$ NACE. W wyniku przeprowadzonych badań zidentyfikowano wiodqce pod względem liczby licencjonowanych patentów kraje Europy, wyznaczono dynamikę rozprzestrzeniania własności przemysłowej w gospodarce europejskiej oraz ustalono branże, w których powstajqce nowe rozwiqzania przemysłowe sq przedmiotem komercjalizacji z wykorzystaniem kontraktów licencyjnych.

Słowa kluczowe: patent, licencjonowanie patentów, komercjalizacja własności intelektualnej. 
